Zabytkoznawstwo i Konserwatorstwo XIII, Torun 2011

\title{
Washi kozo i funori jako materiały do licowania przenoszonych malowideł ściennych
}

$\mathrm{O}$ ddzielenie malowidła ściennego od podłoża konstrukcyjnego i ponowne umieszczenie go w pierwotnym miejscu lub na podłożu zastępczym jest wyjątkowym zabiegiem konserwatorskim, wymagajacym szczególnego uzasadnienia, a także właściwego doboru materiałów i metod oraz wysokich umiejętności konserwatorskich. Transfer zawsze jest bardzo ryzykowny - w wyniku przenoszenia moga zostać utracone wartości historyczne i kulturowe malowideł, a zmiana lokalizacji może negatywnie oddziaływać na estetyczny i emocjonalny odbiór zabytku. Przeniesienie malowidła powoduje zmianę stratygrafii, składu, struktury, wpływa na jego właściwości fizykochemiczne i optyczne. Obecnie konserwatorzy są świadomi tych zagrożeń i uważają przeniesienie malowidła za rozwiązanie ostateczne, dopuszczalne wówczas, gdy nie ma innej lub lepszej metody działania. W ostatnim ćwierćwieczu liczba wykonywanych zabiegów przenoszenia malowideł zmniejszyła się wyraźnie w stosunku do wcześniejszych 50 lat. To wynik większej rozwagi w podejmowaniu decyzji. Pomimo postępu w rozwoju technik konserwacji malowideł in situ, niekiedy transfer pozostaje jedynym lub najskuteczniejszym sposobem zabezpieczenia zabytku przed postępującym niszczeniem. Dla tych nielicznych, lecz bardzo ważnych przypadków istnieje potrzeba opracowania 
odpowiednich metod, posiadania właściwych materiałów i narzędzi, czasem ich udoskonalania i stworzenia alternatywnych rozwiązań, możliwych do zastosowania w indywidualnych przypadkach. W odległych od siebie ośrodkach konserwatorskich sa podejmowane próby wykorzystania nowych materiałów, często znanych od wieków, lecz używanych do innych celów.

Idea przenoszenia malowideł ściennych i sposoby jej urzeczywistnienia zostały wypracowane w Europie, na Półwyspie Apenińskim - w miejscu wielkiej tradycji i zasobów malarstwa ściennego. Tam też najwięcej dekoracji ściennych poddano takim zabiegom. Pierwsze informacje o przenoszeniu malowideł pochodzą z czasów starożytnych. Przekazy Witruwiusza ${ }^{1}$ i Pliniusza ${ }^{2}$ wspominaja o sprowadzaniu do stolicy pięknych malowideł z rzymskiej prowincji. Dowody popularności takich działań odnaleziono w trakcie wykopalisk archeologicznych w Pompejach i Herkulanum, gdzie na ścianach domów odkryto malowidła pochodzące $z$ innych budynków. Wydaje się, że w średniowieczu umiejętność przenoszenia malowideł zanikła, przynajmniej nie zachowały się przykłady ani pisane wzmianki z tej epoki. Do metody opracowanej w czasach rzymskich powrócono w okresie renesansu3. Wówczas, podobnie jak w starożytności, dekoracje ścienne przenoszono metodą stacco a masello, polegająca na oddzieleniu malowideł wraz z zaprawą i murem. Techniki przenoszenia malowideł rozwinęły się znacząco w drugiej połowie XVIII wieku, kiedy włoski konserwator Antonio Contri wynalazł technikę stacco, polegająca na oddzieleniu malowidła wraz z tynkiem, a następnie technikę strappo, za pomocą której możliwe było oderwanie samej warstwy malarskiej. Zabieg transferu malowideł stawał się coraz bardziej popularny, a jego stosowanie

1 Witruwiusz, O architekturze ksiag dziesiéć, Warszawa 1956, s. 36.

2 Pliniusz Starszy, Historyi Naturalnej Ksiag XXXVII, Poznań 1845, s. 251.

3 Przykłady takich działań opisują m.in.: G. Botticelli, Metodologia di Restauro delle Pitture Murali, Centro Di, Firenze 1992, s. 111; M. Ostaszewska, Przenoszenie malowidet ściennych w Polsce, „Biblioteka Muzealnictwa i Ochrony Zabytków”, seria B, t. 55, Warszawa 1979, s. 54; Z. Medwecka, Zastosowanie tatwo rozpuszczalnej blony z. tworaywa sztucznego pray zdejmowaniu i przenoszeniu malowidta ściennego na pobiale na nowe podto:̇e, „Ochrona Zabytków”, 1996, nr 2, s. 63; H. Grzesikowa, Przenoszenie malowideł ściennych na podtoża zastęprze. Próby mykonane w Instituto Centrale del Restauro w Rzymie, „Biblioteka Muzealnictwa i Ochrony Zabytków”, seria B, t. 11, Warszawa 1965, s. 221. 
coraz szerzej rozprzestrzeniało się poza Półwysep Apeniński. Po latach podziwu dla umiejętności estrattisi ${ }^{4}$ dostrzeżono negatywne konsekwencje tej praktyki. Przenoszenie malowideł w celach handlowych i kolekcjonerskich spotykało się ze wzmożoną krytyką. Równocześnie metoda znajdowała coraz większe zastosowanie w działaniach zabezpieczających obiekty zabytkowe. Na dużą skalę malowidła przenoszono w miejscach, w których zabytki ucierpiały w wyniku działań wojennych lub klęsk żywiołowych. Przenoszono je z niezabezpieczonych stanowisk, chroniąc je przed kradzieżą lub dewastacją. Po metodę transferu sięgano, gdy odizolowanie malowideł od czynników niszczących wydawało się niemożliwe lub gdy stopień destrukcji obiektu stawiał pod znakiem zapytania konserwację in situ. Techniki przenoszenia wykorzystywano do rozwarstwiania leżących na sobie malowideł, dając szansę na ekspozycję poszczególnych warstw polichromii.

W innych częściach świata malowidła zaczęto przenosić dużo później niż w Europie i na znacznie mniejszą skalę. W dawnej Japonii, gdzie dominowała architektura drewniana, nie było tradycji malarstwa ściennego. Do dziś zachowało się tam zaledwie kilka zabytkowych dekoracji wykonanych na tynku naniesionym na podłoże kamienne lub drewniane, a tylko trzy są wpisane na listę Kokuho ${ }^{5}$. Japonia przez wieki pozostawała w izolacji od świata zachodniego i rozwijających się w nim idei. Japońskie podejście do ochrony zabytków architektury różniło się od ukształtowanego w Europie. Celem prac konserwatorskich nie było zachowywanie oryginalnej substancji zabytku, lecz jego odtworzenie w pierwotnym kształcie, zgodnie ze starą technologia. W ostatnich dekadach Japończycy docenili jednak wartość oryginalnych pozostałości malowideł i objęli je szczególną opieka. W wyniku rozwoju nauki konserwatorskiej, bazującej na nowoczesnej aparaturze technicznej i wiedzy czerpanej sukcesyw-

4 Specjaliści zajmujący się wyłącznie przenoszeniem malowideł ściennych.

Jest to lista najważniejszych narodowych pamiątek stworzona przez japońskie Ministerstwa Edukacji, Kultury, Sportu, Nauki i Technologii. Znajdują się na niej malowidła z grobowca Takamatsuzuka w Nara z ok. 700 r., malowidło ścienne ze świątyni Horyuji Kondo - uważane za najstarsze malowidło na tynku w Japonii, oraz malowidła w wewnętrznym sanktuarium Amida-do w świątyni Hokai-ji w Kioto. Poza listą znajdują się szczątki malowideł w Byodo-in Hoodo w Uji (powstałe przed 900 r.) oraz w Daigo-ji Ryokai Mandala w Kioto (z 951 r.). 
nie z zagranicznej literatury i uczestnictwa $\mathrm{w}$ międzynarodowych konferencjach, oryginalna substancja zabytkowa szczątkowo zachowanych malowideł jest poddawana głównie konserwacji zapobiegawczej. Do ich badania są stosowane tylko metody nieniszczące. Kiedy wyjątkowo są dopuszczane działania inwazyjne, japońscy konserwatorzy próbują zaadaptować metody od lat wykorzystywane w Europie i zmodyfikować je przez zastosowanie wysokiej jakości materiałów wywodzących się z ich lokalnej tradycji, takich jak ręcznie wytwarzany papier (washi) i naturalny środek konsolidacyjny funori. Ekologicznym materiałom w konserwacji towarzyszą produkty nowoczesnych technologii.

Japońska tradycja papiernicza liczy już 1400 lat. W 720 roku miejscowy kronikarz Nihonshoki zanotował, że sztuka otrzymywania papieru została zapoczątkowana w tym kraju w 610 roku przez koreańskiego mnicha o imieniu Donchyou (Doncho). Wytwarzał on papier sposobem wynalezionym około 105 roku przez Chińczyka Tshai Lun (Cai Lun), który jako pierwszy do produkcji tego materiału wykorzystywał macerowaną korę drzew morwowych, odpady z konopii, stare szmaty i sieci rybackie ${ }^{6}$. Rozprzestrzenianie się buddyzmu w Japonii sprzyjało rozwojowi papiernictwa. Mnisi potrzebowali papieru do przepisywania ky $\bar{o}^{-7}$ i sporządzania notatek podatkowych. Papier otrzymywany chińskim sposobem okazal się zbyt delikatny i wkrótce książę regent Shotoku Taishi zaproponował, by produkować go z mieszaniny włókien kory kozo (krzewy z rodziny morwowatych: Broussonetia papyrifera, Broussonetia kazinoki $)^{8}$ i konopii (asa). Krzewy kozo rosły dziko w górach, na wyspach Shikoku i Kiusiu. Wraz z rozwojem papiernictwa ich uprawa rozprzestrzeniła się w różnych regionach Japonii. Z czasem do wyrobu papieru zaczęto też używać kory dziko rosnącej gampi (rośliny z rodziny wawrzynkowatych: Wikstroemia

6 Tshai Lun zwyczajowo uchodzi za wynalazcę papieru, ale papier w Chinach był znany znacznie wcześniej. Najstarsze odnalezione artefakty, w pobliżu Dunhuang, są datowane na VIII w. p.n.e. W Chinach papier do pakowania był używany od II w. p.n.e., a do celów piśmienniczych od III w. p.n.e. Tshai Lun zebrał doświadczenia poprzedników i udoskonalił technologię, przyczyniając się do rozpowszechnienia produkcji. Tsuen-Hsuin Tsian, J. Needham, Science of Civilization in China, vol. 5, part 1: Paper and Printing, Cambridge 1985, s. 38-41.

Japońska nazwa sutry - księgi religijne zawierające nauki Buddy.

8 Rośliny osiągają wysokość 3-5 m, a średnica ich gałęzi dochodzi do $10 \mathrm{~cm}$. 
diplomorpha, Diplomorpha sikokiana), ale najczęściej wykorzystywany surowiec stanowiło kozo. Pod patronatem księcia Shotoku techniki wytwarzania papieru popularyzowano w kraju - powoli ewoluowały one do metody nagashizuki? , polegającej na czerpaniu papieru przez wielokrotne zanurzanie sit w zawiesinie włókien. W nowej metodzie włókna odkładały się na formie w takiej liczbie warstw, jaka była niezbędna do uzyskania odpowiedniej grubości papieru. Powstanie i rozwój techniki nagashizuki stał się możliwy dzięki środkowi pomocniczemu, lepkiej substancji neri ${ }^{10}$. Środek ten był niezbędny do równomiernego rozprzestrzeniania się włókien w zawiesinie, przedłużał czas odpływu wody, ułatwiał formowanie arkuszy, a następnie ich rozdzielanie. Neri przygotowywano z korzeni lub kory różnych roślin ${ }^{11}$, ale najczęściej używano wyciagu z korzenia taroro aoi. Pod względem chemicznym neri jest wodnorozpuszczalnym kompleksem polisacharydów o podobnym składzie do hemiceluloz i pektyn oraz o makroczasteczkowej budowie podobnej do celulozy. Opracowana na przełomie VIII i IX wieku metoda ręcznego wyrobu papieru jest stosowana w Japonii do dziś, a otrzymywane w ten sposób arkusze sa nazywane washi, co w dosłownym tłumaczeniu oznacza „papier japoński”" ${ }^{2}$.

Procedura uzyskiwania washi kozo składała się z szeregu etapów technologicznych, których ścisłe przestrzeganie zapewniało otrzymanie papieru niezwykle wysokiej jakości. Pod koniec zimy jednoroczne łodygi koz̧o były ścinane i wiązane w pęczki tej samej wielkości. Umieszczano je w drewnianych beczkach i poddawano działaniu pary wodnej ułatwiającej zdjęcie kory. Stopniowo usuwano zewnętrzne warstwy kory: czarna (kurokawa) i zieloną (nazekawa), pozostawiając jedynie warstwę białą (sbirokawa), zbudowana z długich włókien powiązanych pektynami. Następny etap pracy miał na celu usunięcie niepożądanych substancji i pozostawienie samych włókien. Shirokawe oczyszczano z zanieczyszczeń w nurcie

9 Przeciwieństwem nagashizuki jest zachodni sposób otrzymywania papieru - metoda tamezuki, polegajaca na czerpaniu papieru przez jednokrotne zanurzenie formy.

10 W zależności od regionu środek ten był nazywany tamo, nebeshi, sana, nibe lub nori.

11 Wykorzystywano korzenie aogiri i ginbaiso oraz korę noriutsugi.

12 Nazwa pochodzi od wa-Japonia i shi-papier. 
czystych rzek, osuszano na zimnym powietrzu lub na śniegu i bielono w słońcu ${ }^{13}$. Następnie białe łyko gotowano w kadziach z alkalicznym roztworem, aż stawało się bardzo miękkie ${ }^{14}$. W czasie gotowania pektyny przechodziły w kwasy, które łatwo rozpuszczały się w wodzie. Ugotowany materiał płukano w wiklinowych koszach. W lodowato zimnej wodzie ręcznie usuwano nawet najmniejsze zanieczyszczenia ${ }^{15}$. W kolejnym etapie przygotowywano pulpę, rozluźniając włókna delikatnymi uderzeniami drewnianego młotka i przystępowano do formowania arkuszy metoda nagashizuki $i^{16}$. Rozbite włókna wkładano do kadzi (sukibune $)^{17}$, dodawano neri i zawiesinę mieszano bambusowymi pałeczkami osadzonymi w drewnianej ramie. Narzędziem niezbędnym do wytworzenia arkusza papieru była forma (su-keta), składająca się z ruchomego ekranu $(s u)^{18}$ i mocującej go drewnianej ramy $(k e t a)^{19}$. Wprowadzana w ruch zawiesina przemieszczała się w su-kecie, po czym różnorodnie ukierunkowane włókna osiadały na formie w jednolitej warstwie. Czynność tę wielokrotnie powtarzano. Gdy proces czerpania papieru był zakończony, ekran wysuwano z formy, a mokre arkusze papieru gromadzono w stosach, z których pod naciskiem usuwano nadmiar wody. W ostatnim etapie procesu produkcji rozdzielone kartki suszono i bielono na słońcu ${ }^{20}$.

13 Obecnie do bielenia włókien stosuje się głównie podchloryn sodu, ale tradycyjne metody czasami jeszcze są używane.

14 W dawnych czasach używano ekstraktu z popiołu drzewnego. Obecnie wykorzystuje się wapno gaszone, sodę amoniakalną lub sodę kaustyczna.

15 Proces płukania i oczyszczania ugotowanych włókien nosi nazwę chiritori.

16 T. Barrett, Japanese Papermaking: Traditions, Tools, and Techniques, Weatherhill, New York 1983, s. 44.

17 Kadzie tradycyjnie wykonywano $\mathrm{z}$ drewna sosnowego lub cedrowego. Współczesne sukibune są sporządzane z nierdzewnej stali.

$18 S u$ wykonywano z bambusowych patyczków, połączonych jedwabnymi nićmi. Wykonanie tego elementu wymagało dużych umiejętności. Jest to najdroższe narzędzie w japońskim papiernictwie.

19 Kete sporządzano z drewna cedrowego. Musiała być lekka i bardzo wytrzymała. Jej trwałości dowodzi współczesne używanie narzędzi liczących kilkaset lat.

20 We współczesnej produkcji washi kozo arkusze papieru często są suszone za pomocą elektrycznych narzędzi, czasami wspomaganych para. Uważa się, że najwyższa jakość maja papiery naturalne suszone na słońcu. 
Cechą charakterystyczną ręcznie sporządzanego papieru japońskiego jest szczególna trwałość ${ }^{21}$. Długowieczność washi wynika z nieobecności ligniny i z wysokiego stopnia polimeryzacji i krystalizacji. Lignina jest naturalnym składnikiem włókien roślinnych, ale pozostawiona w papierze powoduje jego kruchość i zmiany zabarwienia. W procesie produkcji washi lignina jest skutecznie usuwana, a w skład papieru wchodzą włókna roślinne zbudowane z długich łańcuchów celulozy oraz odpowiedzialnych za krystalizację hemiceluloz. O wytrzymałości mechanicznej papierów w dużym stopniu decyduje rozmiar włókien. Papier mający długie włókna jest mocniejszy, ponieważ są one splecione w bardziej złożony sposób. Z materiałów używanych do produkcji papieru włókna kozo charakteryzują się największą długością (średnio $7,3 \mathrm{~mm}$ ) 22 i najwyższą wytrzymałością mechaniczną. Włókna w papierach gampi (ok. 5,0 mm) i mitsumata ${ }^{23}$ (około 3,2 mm) maja podobną długość do odpowiedników w papierach otrzymywanych ze szmat bawełnianych i ścieru drzewnego, ale obecność hemiceluloz sprawia, że ich trwałość jest większa ${ }^{24}$. Na właściwości mechaniczne papieru wpływa również stosunek długości włókien do ich grubości. W kozo wynosi on 510, w gampi 490, a w mitsumata 420. W papierach wytwarzanych ze ścieru drzewnego „metoda zachodnia” relacje te są znacznie niższe. Zawierają się w wartościach od 86 (w papierach z włókien drewna miękkiego) do 60 (w papierach z drewna twardego).

Kozo jest najpopularniejszym włóknem stosowanym w japońskim papiernictwie. Aż 90\% współczesnych papierów, wykonywanych tradycyjna metoda, jest zbudowanych $z$ tych włókien ${ }^{25}$. Ze względu na wyjątkowa trwałość jest używany w tradycyjnej architekturze jako wypełnienie ścian (shoji) i przesuwanych drzwi (fusuma), do produkcji parasolek, lampionów,

21 Potwierdzeniem trwałości washi jest znaczna liczba ponadtysiącletnich artefaktów. Najstarszy z nich pochodzi z $702 \mathrm{r}$.

22 Niektóre źródła mówią o długości włókien kozo sięgającej $15 \mathrm{~mm}$.

23 Włókien z kory mitsumata, krzewu z rodziny wawrzynkowatych (Edgeworthia papyrifera chrysanthea, Edgeworthia papyrifera), używano w japońskim papiernictwie od $1614 \mathrm{r}$.

${ }^{24} \mathrm{~W}$ papierach otrzymywanych z pulpy bawełnianej lub drzewnej znajduje się niewiele hemiceluloz, ponieważ ulegaja zniszczeniu w procesie produkcji. Wysoka zawartość hemiceluloz w papierach japońskich pomaga w sklejaniu się włókien.

25 T. Barrett, op. cit., s. 22. 
strojów i zabawek. Odpowiednia chłonność sprawia, że stanowi podłoże drzeworytów, rysunków tuszem i kaligrafii. Wyjątkowe właściwości czynia go włóknem najbardziej odpowiednim do prawie każdej konserwacji papieru - jest wykorzystywany do osłaniania sygnatur, mocowania zawieszek, wzmacniania okładek książek i reperowania rozdarć. Wieloletnie badania i rozwój papiernictwa doprowadziły do wynalezienia maszyny tanmo-shoshiki, za pomocą której jest produkowany papier maszynowy, wyglądający bardzo podobnie do washi, mający jednak odmienne właściwości (kikaizuki washi). W maszynowym procesie produkcji nie używa się neri, a arkusze papieru sa natychmiast zdejmowane z ekranu i suszone. Tą metoda produkuje się wiele odmian papieru, różniących się składem i zastosowaniem. Wśród nich są odmiany wykonane w 100\% z włókien kozo, jak i zawierające domieszki innych włókien, nawet ścieru drzewnego. Maszynowo produkowany papier jest co najmniej dziesięciokrotnie tańszy od washi i szeroko wykorzystywany do wielu celów: do pakowania prezentów i słodyczy, jako materiał do origami, do sporząqdzania talizmanów używanych w świątyniach i miejscach kultu, do pisania listów, drukowania zaproszeń, życzeń i certyfikatów. Stosunkowo dobry stosunek jakości do ceny sprawia, że maszynowo wytwarzane papiery kozo znajduja szerokie zastosowanie w kaligrafii, w odbijaniu drzeworytów i w konserwacji zabytków poza Japonią (il. 1, 2).

Innym materiałem, mającym w Japonii wielowiekową tradycję, jest funori - naturalny konsolidant otrzymywany z morskich wodorostów, wykorzystywany m.in. jako składnik tradycyjnych zapraw wapiennych shik$k u{ }^{26}$. Od XVII wieku funori było używane również do usztywniania tkanin i papierów oraz jako składnik do produkcji ceramiki i innych materiałów budowlanych ${ }^{27}$. Pod względem chemicznym jest polimerem węglowodanowym, zbudowanym głównie z galaktozy. Funori może być otrzymywane $z$ trzech gatunków czerwonych morskich wodorostów występujących u wybrzeży wysp japońskich: Gloiopeltis tenax (mafunori), Gloiopeltis com-

26 Zaprawy tynkarskie przygotowywane $\mathrm{z}$ wapna gaszonego, uzyskiwanego z muszli ostryg, tłuczonych włókien konopnych, środków klejących, takich jak funori i czerwone glony tsunomata, czasami z dodatkiem piasku lub gliny. Pokrywano nimi ściany, sufity i podłogi grobowców skalnych, domów i zamków.

27 D. J. Chapman, Seaweeds and Their Uses, London-New York 1980. 
planata (hana-funori) lub najczęściej wykorzystywanego Gloiopeltis furcata (fukuro-funori) ${ }^{28}$. Wodorosty te przez caly rok porastają nadmorskie skały. Zbiera się je latem na północy kraju i zimą na południu. Na brzegu morskim są sortowane i suszone, a następnie wysyłane do manufaktur. Tam są myte i moczone w wodzie w celu usunięcia soli, pleśni i innych zanieczyszczeń. W dzisiejszych sposobach obróbki wodorosty są zmiękczane za pomoca pary i wybielane za pomoca rozcieńczonych roztworów wodorotlenku potasu lub nadtlenku sodu. Po płukaniu zabarwienie wodorostów zmienia się z czerwonego na pomarańczowożółte. Następnie układa się je na matach oraz przez 3-4 miesiące suszy i poddaje bieleniu na słońcu. Po wyschnięciu arkusze są cięte i zwijane w rolki. W celu uzyskania środka konsolidującego pokruszony suchy materiał rozpuszcza się w gorącej wodzie. Współczesne źródła podaja wiele metod otrzymywania funori, różniących się przygotowaniem składników, ich proporcjami, czasem i temperaturą rozpuszczania wysuszonych wodorostów w wodzie oraz postępowaniem w trakcie rozpuszczania. Niektóre źródła zalecaja wrzucanie surowego materiału do gorącej wody, inne namaczanie i rozdrabnianie wodorostów przed gotowaniem, jeszcze inne 30-60-minutowe, stopniowe podgrzewanie na małym ogniu. Doprowadzenie roztworu do wrzenia zawsze powoduje obniżenie jego lepkości. Po rozpuszczeniu wodorostów w wodzie, w celu usunięcia nierozpuszczonych części, funo$r i$ jest odcedzane przez tkaniny lub sita. Zakres stężeń otrzymanych roztworów zawiera się w przedziale 1-5\%. W zależności od potrzeby funori może być aplikowane w konsystencji żelu, jaką zachowuje w temperaturze pokojowej, lub w postaci lepkiej cieczy, po podgrzaniu do temperatury około $50^{\circ} \mathrm{C}$. Różnice w kolorze i sile klejenia zależą od procesu produkcji, natomiast lepkość roztworów od gatunku i miejsca pochodzenia rośliny, a także od temperatury rozpuszczania i zawartości soli. Rozpuszczony klej może być przechowywany w lodówce przez kilka dni lub w zamrażarce przez 2-3 tygodnie (il. 3, 4).

W konserwacji zabytków funori jest wykorzystywane do delikatnej konsolidacji papieru, tkanin, łuszczącej lub pudrującej się warstwy malarskiej, a także do prac przy powierzchniach pokrytych folią złotą, srebrna

28 J. S. Swider, M. Smith, Funori: Overview of a 300-Year-Old Consolidant, „Journal of the American Institute for Conservation”, 2005, vol. 44, no. 2, s. 118. 
lub mikąa ${ }^{29}$ W kompozycji z klejem glutynowym jest stosowane do dublowania obrazów, a nawet do wzmacniania struktury obiektów drewnianych $^{30}$. Dzięki niskiemu napięciu powierzchniowemu doskonale zwilża powierzchnie wzmacnianych materiałów. Jest środkiem nietoksycznym, łatwo rozpuszczalnym w wodzie, zapewniającym odwracalność zabiegów konserwatorskich. Po wyschnięciu błony funori są elastyczne i matowe, nie powoduja wybłyszczeń. Pod wpływem ekstremalnego oświetlenia staja się nieco bardziej kruche. W normalnych warunkach wilgotności, temperatury i światła błony funori zachowują się stabilnie, wysoka wilgotność powoduje zaś, że wykazują niską odporność mikrobiologiczną. Według J. Wintera ${ }^{31}$ i C. V. Horie ${ }^{32}$ funori może porastać pleśnią. Pojawienie się jej na malowidłach w grobowcu Takamatsuzuki tłumaczy się około 100\% wilgotnością względna powietrza i obecnością funori w zaprawie wapiennej. W publikacjach opisujących zastosowanie funori w konserwacji zabytków często brakuje opisów metodyki przygotowania roztworów. Japońscy konserwatorzy robią to, opierając się na własnych doświadczeniach, nie odmierzają wagowo składników, a ich gotowość do użycia sprawdzaja palcami.

Tradycja i specyfika japońskiego budownictwa sprawiły, że mieszkańcy tego kraju mają duże doświadczenie w konserwacji papieru, ale skromne w konserwacji malowideł ściennych. Nieliczne fragmenty zabytkowego malarstwa ściennego w Japonii sa obecnie poddawane konserwacji prewencyjnej, a miejscowi konserwatorzy doświadczenie w tej dziedzinie zdobywaja głównie poza swym krajem. Wyjątkiem były prace konserwatorskie, jakie wykonano przy XIII-wiecznych malowidłach ściennych

29 S. Higuchi, Treatment on Painting of Sliding screen and Wall Panels to Prevent Exfoliation in Japan, [w:] Conservation of Far Eastern Art Objects. International Symposium on the Conservation and Restoration of Cultural Property, IIC, Tokyo 1979, s. 69-77.

30 K. Tsujimoto, On My Five Years Experience of Repairs on Wooden Statues in the United States, [w:] Conservation of Far Eastern Art Objects. International Symposium on the Conservation and Restoration of Cultural Property, IIC, Tokyo 1979, s. 125-132.

31 J. Winter, Natural Adhesives in East Asian Paintings, [w:] Adhesives and Consolidants, ed. by N. S. Brommelle, E. M. Pye, P. Smith, IIC, 1984, s. 117-120.

32 C. V. Horie, Materials for Conservation. Organic Consolidants, Adhesives and Coatings, London 1992, s. 142. 
w świątyni Hokai-ji w Kioto $^{33}$. Decyzja o konieczności ingerencji konserwatorskiej w sanktuarium Amida-do ${ }^{34}$ została spowodowana silnym trzęsieniem ziemi, które nawiedziło region Kansai ${ }^{35}$ w styczniu 1995 roku. Doprowadziło ono do osłabienia drewnianej konstrukcji budowli i zagrożenia dla malowideł ściennych ${ }^{36}$. W obawie przed zniszczeniem malowideł przez kolejne trzęsienia ziemi w latach 1996-2000 przeprowadzono prace konserwatorskie. W celu zabezpieczenia malowideł przed niszczącym działaniem kolejnych wstrząsów zdecydowano się na oddzielenie ich od podłoża, wzmocnienie tynku, umieszczenie płatów na podłożach pośrednich i zamontowanie ich w pierwotnym miejscu. Zajęli się tym konserwatorzy z firmy Oka Bokkodo Co., Ltd., specjalizującej się w produkcji ręcznie wytwarzanego papieru, konserwacji obiektów zabytkowych wykonanych z papieru i malowideł na jedwabiu. W momencie rozpoczęcia prac wykonawcy nie mieli żadnego doświadczenia w zakresie przenoszenia malowideł ściennych. Podstawy teoretyczne takich zabiegów zaczerpnęli z publikacji ICCROM-u. Po oczyszczeniu, podklejeniu łusek warstwy malarskiej i skonsolidowaniu tynku ${ }^{37}$ powierzchnię malowideł zabezpieczono metodą stosowaną do dublowania jedwabnych obrazów w firmie konserwatorsko-papierniczej Oka Bokkodo ${ }^{38}$. Licowanie składało się

33 Świątynia będąca „narodowym skarbem” powstała w okresie Heian (794 -1185). Obecnie jest najstarszym zachowanym w całości zespołem architektury buddyjskiej w Japonii.

34 Jest to klasyczny przykład sali poświęconej Amida-Buddzie. We wnętrzu sanktuarium znajduje się posag Amida Nyorai (Amitabha), a górne partie otaczających go ścian ozdabiają malowidła podzielone drewnianą konstrukcją na 23 pola przedstawieniowe. Dwanaście malowideł prezentuje unoszące się w powietrzu bóstwa, na ośmiu ukazano siedzącego Amida Nyorai, a tematem trzech pozostałych sa ornamenty i instrumenty muzyczne.

35 Region o historycznym znaczeniu i prężnie rozwijającej się gospodarce, na terenie którego znajdują się m.in. Kioto, Nara, Osaka i Kobe.

36 Malowidła w sanktuarium zostały wykonane na tynku naniesionym na deski oraz na tynku narzuconym na gliniastą zaprawę wypełniającą drewnianą kratownicę.

37 Malowidła oczyszczono na sucho za pomoca pędzli. Łuski warstwy malarskiej podklejono roztworami funori i kleju glutynowego. Tynk skonsolidowano powierzchniowo roztworem Paraloidu B-72.

38 I. Oka, A Dry Method for Removing the Backing Papers from Japanese Paintings, [w:] The Conservation of Far Eastern Art, Preprints of the Contributions to the Kyoto Congress, 
z kilku warstw nośników przyklejanych za pomoca funori. W pierwszej kolejności przyklejono dwie warstwy bibuły wiskozowej o ukierunkowanych włóknach ${ }^{39}$. Bibuła użyta $\mathrm{w}$ drugiej warstwie miała większą gramaturę i nanoszono ja prostopadle do kierunku włókien warstwy pierwszej. Następnie przyklejono po jednej warstwie płótna konopnego, washi kozo oraz tektury. Kolejne warstwy licowania przyklejano po wyschnięciu poprzednich. Malowidła oddzielono od podłoża wraz z tynkiem, posługując się narzędziami wykonanymi z drewna bambusowego. Odseparowane płaty ${ }^{40}$ ułożono na stole licem do dołu i wykonano standardowe operacje na odwrociach ${ }^{41}$. Następnie płaty odwrócono licem do góry i za pomoca wody usunięto wszystkie warstwy licowania. W ostatnim etapie prac malowidła przytwierdzono do podłoży pośrednich ${ }^{42}$. Na odwrociu jednego $\mathrm{z}$ nich umieszczono tytanową tablicę informującą o przebiegu konserwacji i użytych materiałach ${ }^{43}$.

19-23 September 1988, ed. by J. S. Mills, P. Smith, K. Yamasaki, International Institute for Conservation of Historic and Artistic Works, IIC, Kyoto 1988, s. 69-72.

39 Wiskoza jest zregenerowaną celulozą. Nośniki z włókien wiskozowych są stosunkowo niedrogie. Wykazują pewien spadek wytrzymałości po zamoczeniu, ale nie jest on tak duży jak w przypadku papieru. Proces otrzymywania wiskozy został odkryty w 1891 r. Komercyjnie wiskoza jest produkowana od 1910 r.

40 Płatem nazywamy malowidło w czasie zdejmowania i opracowania odwrocia, a także licową część transferu wraz ze wszystkimi warstwami dodanymi do odwrocia. Definicję podaję za: M. Ostaszewska, op. cit., s. 8.

41 Prace polegały na usunięciu nadmiaru zaprawy, uzupełnieniu jej ubytków oraz konsolidacji roztworem Paraloidu B-72. Dodatkowo wzmocniono odwrocie włóknami węglowymi naniesionymi z roztworem Paraloidu B-72. Na wzmocnione odwrocie naniesiono warstwę interwencyjną, wykonana z żywicy epoksydowej z „mikrobąbelkami” - wykonawcy nie podają bliższych informacji o tym materiale, prawdopodobnie były to szklane baloniki.

42 Zastosowano podłoża o konstrukcji przekładkowej z rdzeniem w formie plastra miodu i okładzinami z laminatów węglowych. Podłoża zastępcze połączono z odwrociami malowideł za pomoca polimetakrylimidowej pianki Rohacel, prod. Evonic Industries.

43 Założenia i przebieg prac konserwatorskich przy malowidłach w światyni Hokai-ji zostały opisane w: R. Kamei, The Wall Painting of Hokaiji Temple, „Conservation", 2004, no. 8, s. 6-19, 51. 
Oddzielenie i ponowne zamontowanie malowideł w świątyni Hokai-ji w Kioto zakończyło się powodzeniem. W czasie wykonywania transferu, który zawsze jest zabiegiem ryzykownym, malowidła nie uległy uszkodzeniu, a zadowoleni wykonawcy zastosowany przez nich sposób postępowania nazwali „japońską metoda przenoszenia malowideł ściennych”. W rzeczywistości posłużono się metodą popularną w Europie od końca XVIII wieku ${ }^{44}$. Do zabezpieczenia malowideł użyto dwóch materiałów tradycyjnie wytwarzanych w Japonii i stosowanych tam do konserwacji zabytków z papieru i jedwabiu. Pozytywny rezultat pierwszego w Japonii transferu malowideł ściennych sprawił, że miejscowi konserwatorzy uznali, że washi kozo i funori mogą być szeroko wykorzystywane do tego celu, również poza Japonią. Poszerzenie możliwości aplikacyjnych tych materiałów jest spójne z polityka gospodarczą i kulturalną Japonii, dążącą do ochrony i popularyzacji elementów narodowej tradycji. Przykładem takiego przekonania był zamiar wykorzystania washi kozo i funori do przenoszenia malowideł ściennych w komorze grobowej mastaby Idut w Sakkarze ${ }^{45}$.

W przeciwieństwie do Japonii, Egipt ma wielką tradycję malarstwa ściennego, sięgająca początków cywilizacji ${ }^{46}$. Wiele starożytnych malowideł zachowało się w grobowcach dzięki temu, że przez tysiące lat były zasypane piaskiem. W stosunkowo stabilnych warunkach ulegały procesom starzeniowym, ale tempo destrukcji zwiększało się gwałtownie po odkopaniu grobowców w czasie prac archeologicznych. Wrażliwe materiały zaczęły reagować na nowe warunki temperatury i wilgotności, co powodowało deformacje i ubytki polichromii. Niezbędne prace konserwatorskie w starożytnych grobowcach od lat prowadzą liczne misje zagraniczne, korzystające z doświadczenia własnej kadry oraz znanych im metod i środków. W rezultacie Egipt i jego zabytki stały się konserwatorskim międzynarodowym poligonem doświadczalnym, co niedawno zosta-

44 Do oddzielenia malowideł w świątyni Hokai-ji użyto metody stacco, polegającej na oddzieleniu od podłoża warstwy malarskiej z tynkiem.

45 Prace konserwatorskie były realizowane w ramach Egyptian-Japanese Mission for Mastaba Idout, finansowanej z grantów Uniwersytetu Kansai w Osace, Fundacji Sumitomo oraz Japońskiego Stowarzyszenia Promocji Nauki. Sponsorom Misji zależało na propagowaniu japońskiej kultury poza granicami kraju.

46 Najstarsze zachowane egipskie malowidło ścienne wykonane na tynku, znajdujące się w grobowcu w Hierakonpolis, pochodzi z ok. 3100 r. p.n.e. 
ło ostro skrytykowane ${ }^{47}$. Miejscowe służby konserwatorskie są zbyt słabe, by merytorycznie ocenić proponowane rozwiązania i określić standardy, zwłaszcza gdy urzędnicy chca wypromować siebie jako mentorów nowej metody i czerpią korzyści z międzynarodowej współpracy. Historia konserwacji malowideł ściennych w Egipcie pamięta wiele konserwatorskich rozwiązań. Są wśród nich takie, które uratowały zabytki, jak i rozwiązania, które doprowadziły do zniszczeń ${ }^{48}$. Pamięć o tych drugich uczy pokory i przypomina o obowiązku sprawdzenia możliwości aplikacji nowej technologii, zanim zostanie ona zastosowana na szeroką skalę.

Malowidła w komorze grobowej mastaby Idut w Sakkarze sa przykładem obiektu, którego proces niszczenia został spotęgowany po archeologicznym odkryciu ${ }^{49}$. Dopływ suchego powietrza z pustyni, a przede wszystkim dobowe i sezonowe wahania temperatury i wilgotności powodowały zmiany objętościowe podłoża skalnego i krystalizację soli, co było przyczyną odpadania od podłoża kolejnych fragmentów malowide ${ }^{50}$. W 2004 roku zawiązała się egipsko-japońska misja. Jeden z jej celów stanowiła konserwacja niszczejącej polichromii. Egipska strona misji, świadoma braku odpowiednich umiejętności, nie podejmowała się realizacji zadania. Koncentrowała się na obowiązkach administracyjnych, kontroli poczynań zagranicznych partnerów i czerpaniu korzyści ze współpracy. Również strona japońska nie wyrażała gotowości wykonania trudnych i czasochłonnych prac konserwatorskich. Finansując działania misji,

47 Ch. Leblanc, Response to Z. Hawass, [w:] Egyptology at the Dawn of the Twenty-first Century. Proceedings of the Eighth International Congress of Egyptologysts, Cairo, 2000, vol. 3, ed. by Z. Hawass, Cairo-New York 2002, s. 66.

48 W przeszłości do konserwacji malowideł ściennych w Egipcie stosowano m.in. szkło wodne, wosk pszczeli i parafinę.

49 Grobowiec został odkryty w 1927 r. przez G. M. Firtha. Czas powstania mastaby określa się na ok. 2360 r. p.n.e. Grobowiec był przygotowany dla królewskiego wezyra Ihy, ale pochowano w nim córkę faraona Unisa lub Teti. Malowidła w komorze grobowej przedstawiają wiszące, wzorzyste tkaniny, żywność, łoże oraz inskrypcje.

50 R. Rogal, Mastaba Idut w Sakkarze. Prayczyny destrukecji polichromii ściennych, [w:] Badania technologii $i$ technik malarskich, konserwacja dziet sztuki, kopia. Ksiega pamiatkowa z. okazji jubileuszu 50-lecia pracy dedykowana prof. dr. art. kons. Józefowi Flikowi, pod red. J. Olszewskiej-Świetlik, Torun 2007, s. 253-265. 
chciała promować japońską kulturę przez zastosowanie materiałów zakorzenionych w jej tradycji. Zamierzeniem obu stron było firmowanie konserwacji, ale żadna $z$ nich nie chciała lub nie potrafiła zrealizować zadania konserwatorskiego. W tej sytuacji poproszono o pomoc polskich konserwatorów, mających doświadczenie w przenoszeniu malowideł ściennych, wykonujących podobne prace w Egipcie ${ }^{51}$. Po rozpoznaniu stanu zachowania polichromii i przyczyn jej niszczenia uznano, że konserwacja in situ nie zagwarantuje malowidłom bezpieczeństwa i podjęto decyzję o konieczności ich oddzielenia od podłoża, umieszczeniu na podłożach zastępczych i zamontowaniu w pierwotnym miejscu. Polski program, uwzględniający specyficzne cechy staroegipskich tynków gipsowych, przewidywał zastosowanie bezpiecznego dla malowideł licowania na bazie metakrylanu butylu. Strona japońska odrzuciła tę propozycję, argumentując to względami ekologicznymi. Nawiasem mówiąc, te same względy nie przeszkodziły Japończykom zaproponować roztworów żywic sztucznych w rozpuszczalnikach organicznych do konsolidacji polichromowanego kamiennego sufitu w tym samym pomieszczeniu (il. 6 ).

Rezultatem dyskusji nad programem konserwatorskim była decyzja o wykonaniu próby przeniesienia fragmentu malowidła na ścianie zachodniej komory grobowej z użyciem licowania wykonanego z tradycyjnych japońskich materiałów. Rozległe odspojenia tynku wymagały zabezpieczenia jego krawędzi opaskami wapienno-piaskowymi ${ }^{52}$. Ustabilizowane malowidło utrwalono roztworem Paraloidu B-72 i po odparowaniu rozpuszczalników naniesiono licowanie ${ }^{53}$. Składało się ono z czterech warstw nośników przyklejanych za pomoca funori, przygotowanego zgodnie ze sposobem stosowanym w Oka Bokkodo Co., Ltd. ${ }^{54}$ Pierwszą warstwę

51 Prace przy przeniesieniu pierwszego fragmentu malowidła w 2005 r. wykonywali R. Rogal i A. Fejzer.

52 Opaski wykonano z zaprawy wapienno-piaskowej (1:3 obj.) z dodatkiem 5\% dyspersji wodnej żywicy akrylowej ARGE-ARD.

53 Warstwę malarską i zewnętrzną partię tynku utrwalano 5\% roztworem Paraloidu B-72 w mieszaninie acetonu i toluenu. Bardzo porowata struktura tynku wymagała wielokrotnego nanoszenia roztworu.

54 Wysuszone wodorosty wielokrotnie przemywano wodą w celu usunięcia soli pochodzących z morskiej wody. Wypłukany materiał moczono jeszcze w wodzie przez następne 12 godzin, po czym gotowano i cedzono przez gęste sito. Do przykle- 
nośnika stanowiła bardzo cienka bibuła wiskozowa, o gramaturze $14 \mathrm{~g} /$ $/ \mathrm{cm}^{2}$. Jako drugą warstwę przyklejono bibułę wiskozową o gramaturze $20 \mathrm{~g} / \mathrm{cm}^{2}$. Ponieważ bibuły wiskozowe mają ukierunkowane włókna, nanoszono je w taki sposób, by kierunki włókien obu warstw krzyżowały się. W trzeciej warstwie przyklejono washi kozo o gramaturze $12 \mathrm{~g} / \mathrm{cm}^{2}$. Ostatnią warstwą licowania było płótno bawełniane. Fragment malowidła oddzielono od podłoża wraz z tynkiem gipsowym za pomocą długich noży. Odseparowany płat położono na stole licem do dołu i wykonano standardowe operacje na odwrociu ${ }^{55}$. Osadzony na podłożu zastępczym fragment malowidła odwrócono licem do góry i za pomocą wody usunięto kolejne warstwy licowania ${ }^{56}$ (il. 5, 7, 8).

Praca przy przenoszeniu malowideł w mastabie Idut stanowiła dla autora źródło doświadczeń, ale też okazję do wyciagnięcia wniosków wynikających z obserwacji, porównań i analiz związanych z zastosowaniem tradycyjnych japońskich materiałów. Badania przeprowadzone na modelach wykazały, że nośniki przyklejane za pomoca funori mają stosunkowo małą adhezję do warstw malarskich. Przyczepność takiego licowania może być wystarczająca, jeżeli działają na nie jedynie siły ścinające (równolegle do licowania), ale jest zbyt mała w przypadku odrywania licowania w kierunku prostopadłym. W praktyce oznacza to, że jeżeli w czasie oddzielania tynki będą wymagały odchylania od podłoża, licowanie może się odkleić.

jania nośników stosowano ok. 2\% roztwór kleju. Miał on lekko żółtawe zabarwienie i pH ok. 7,5.

55 Zeszlifowano nadmiar zaprawy, uzupełniono jej ubytki, przeprowadzono konsolidację tynku, przyklejono warstwę dublująca z płótna bawełnianego, przyklejono warstwę interwencyjną ze spienionego poliestyrenu, bezpośrednio na warstwie interwencyjnej zbudowano podłoże zastępcze o konstrukcji przekładkowej, z rdzeniem z Firet Corematu i okładzinami z tkaniny węglowej, wzmocnionymi żywicą epoksydową.

56 Przebieg prac konserwatorskich i zastosowanie japońskich materiałów do transferu malowideł w grobowcu Idut w Sakkarze przedstawiono w: R. Rogal, The Issue of Securing the Mural Paintings in Burial Chamber of Idut Mastaba in Saqqara, [w:] VI Міжнародна Науково-Практична Конферениія, Збереження, Аослідження, Консервачія та Експертиза Музейних Памяток, Київ 2008, s. 161-165; A. S. A. Shoeib, A. I. M. Akarish, R. Rogal, H. Suita, Detachment of Mural Paintings in the Burial Chamber of Mastaba Idout in Saqqara, [w:] Symposium Conservation of Egyptian Mural Paintings and Japanese Contribution for It, Osaka 2008, s. 103-111. 
Znana cecha funori jest jego odwracalność - łatwe rozpuszczanie pod wpływem nieznacznej ilości wody. Właściwość ta jest bardzo cenna przy usuwaniu licowania, ponieważ ogranicza ilość wprowadzanego rozpuszczalnika do obiektu. W przypadku zapraw i warstw malarskich wrażliwych na wodę każda ilość tego rozpuszczalnika jest niebezpieczna. W wodzie rozpuszcza się zarówno guma arabska, będąca spoiwem egipskich warstw malarskich, jak i tynki gipsowe, zawierające pewne ilości anhydrytu ${ }^{57}$ i montmorillonitu ${ }^{58}$. Tak wrażliwe materiały wymagaja starannej impregnacji środkiem zabezpieczającym je przed rozpuszczającym działaniem wody.

Materiały pochodzenia organicznego, przebywające długo w warunkach podwyższonej wilgotności, moga ulec biologicznej destrukcji. Badania porównawcze odporności mikrobiologicznej klejów używanych do przenoszenia malowideł ściennych wykazały, że funori jest jednym z najszybciej atakowanych przez drobnoustroje. Na próbkach funori, przechowywanych w warunkach $100 \%$ Rh, pierwsze mikroorganizmy pojawily się po kilku dniach sezonowania. Atakowi mikrobiologicznemu dłużej opierały się błony polialkoholu winylowego i metylocelulozy. Zgodnie z przewidywaniami najbardziej odporne były błony żywic akrylowych naniesionych $\mathrm{w}$ postaci roztworów w rozpuszczalnikach organicznych ${ }^{59}$. Analiza jakościowa wykazała, że dominująca grupę mikroorganizmów atakujących funori stanowiły bakterie Stenotrophomonas maltophilia ${ }^{60}$. Oprócz nich zidentyfikowano promieniowce Streptomyces sp., niezbyt liczne i słabo zarodnikujące grzyby - Tritinacbium sp., Verticillium sp. oraz strzępki, konidiofory i aparaty konidialne grzyba pleśniowego, prawdopodobnie Botrytis sp. Japońscy konserwatorzy sa świadomi słabej odporności biologicznej funori, ale nie dodają do roztworów środków zabezpieczających, obawiając

57 Bezwodny siarczan wapnia $\mathrm{CaSO}_{4}$, rozpuszczalny w wodzie.

58 Warstwowy krzemian $\mathrm{Al}_{2}\left[(\mathrm{OH})_{2} \mathrm{Si}_{4} \mathrm{O}_{10}\right] \cdot n \mathrm{H}_{2} \mathrm{O}$ o silnych zdolnościach sorpcyjnych i pęczniejących.

59 Badania mikroskopowe próbek wykonała dr J. Karbowska-Berent w Zakładzie Konserwacji Papieru i Skóry UMK w Toruniu.

60 Gramoujemne pałeczki bakterii stenotrophomonas maltophilia zostały zidentyfikowane w systemie BIOLOG (Biolog, Inc. California, USA) przez dr. H. Różyckiego w Zakładzie Mikrobiologii UMK w Toruniu. 
się obniżenia i tak niskich właściwości klejących. Stosują funori, wierząc, że konserwowane obiekty zawsze będa przechowywane w odpowiednich warunkach. O tym, jak złudne może być takie przekonanie, świadczy przykład biologicznej destrukcji malowideł ściennych w grobowcu Takamatsuzuka w Nara, gdzie funori było oryginalnym składnikiem tynków. Zostało zaatakowane w wyniku nieoczekiwanego wzrostu wilgotności względnej powietrza i prawdopodobnie przez przeniesienie drobnoustrojów z zewnątrz (il. 9).

Tradycyjne materiały japońskie, jakimi są washi kozo i funori, z racji ręcznego wytwarzania nie sa tanie, nawet w kraju ich produkcji. Jeżeli uznamy, że materiały te spełniają specyficzne warunki wymagane do licowania wybranych malowideł ściennych, to warto zastanowić się, czy można je zastąpić produktami tańszymi i powszechnie dostępnymi. Zwłaszcza że licowanie jest tymczasowym zabezpieczeniem, które w odpowiednim momencie jest usuwane. Klejem, który - jak się wydaje - mógłby zastapić funori, jest metyloceluloza, używana do przenoszenia malowideł ściennych, a w konserwacji papieru stosowana do podobnych zabiegów jak japoński specyfik. Tak jak funori, metyloceluloza łatwo rozpuszcza się w zimnej wodzie, a użycie jej 4\% roztworu powoduje naniesienie na powierzchnię malowidła niewielkiej ilości wody. Jej odporność mikrobiologiczna jest wyższa, a siła klejenia podobna. Adhezyjne i mechaniczne właściwości licowań na bazie obu klejów porównano w badaniach na modelach malowideł, zabezpieczonych czterema warstwami nośników, takimi, jakie zostały zaproponowane do przenoszenia malowideł w mastabie Idut. Właściwości adhezyjne licowań z obu klejami okazały się bardzo podobne, a wytrzymałość na rozciaganie licowania spojonego metylocelulozą była wyższa (około $120 \mathrm{~N}$ ) niż licowania na bazie funori (około $90 \mathrm{~N}$ ) ${ }^{61}$. Wydaje się więc, że zastosowanie metylocelulozy do przenoszenia suchych malowideł, słabo połączonych z podłożem i niewymagających wyginania płata, stanowiłoby rozwiązanie nieco lepsze i zdecydowanie tańsze.

Substytutem washi kozo jest papier z włókien kozo otrzymywany metoda maszynowa - kikaizuki washi. Oba papiery sa bezkwasowe i maja włókna ułożone w różnych kierunkach, co ułatwia ich przyklejanie na nierównych powierzchniach. Badania wytrzymałościowe obu nośników wy-

${ }^{61}$ Siła, przy której nastąpiło rozerwanie licowania. 
kazały, że wytrzymałość na rozciaganie papieru wyprodukowanego maszynowo jest dwukrotnie niższa ${ }^{62}$ od wytrzymałości washi kozo o tej samej gramaturze ${ }^{63}$. Różnica wynika przede wszystkim z większej długości włókien $\mathrm{w}$ ręcznie wytwarzanym papierze. Technologia produkcji powoduje, że papiery wytwarzane maszynowo sa grubsze, bardziej porowate i chłonne. Kiedy papiery o tej samej gramaturze przesycimy klejem lub połączymy nim dwa arkusze, bardziej wytrzymały na rozrywanie staje się papier produkowany maszynowo ${ }^{64}$. Obszerniejsze pory są wypełnione większa ilością kleju, który decyduje o adhezji licowania i wpływa na wytrzymałość mechaniczną układu nośnik-klej. Japoński papier kozo, otrzymywany maszynowo, bardzo dobrze spełnia funkcję pierwszego nośnika licowania. Przesycony klejem, dobrze układa się na nierównościach powierzchni i łączy z kolejnymi warstwami. Jego duża porowatość powoduje, że w trakcie aplikacji klej może być wprowadzany przez strukturę papieru. Kikaizuki washi kozo jest co najmniej 10-krotnie tańszy od washi kozo (il. 10).

Prace przeprowadzone in situ $\mathrm{w}$ mastabie Idut potwierdzily spostrzeżenia wynikające ze wstępnych badań modelowych. Próby przeniesienia pierwszych fragmentów wykazały, że licowanie zbudowane z washi kozo i funori pozwoliło na oddzielenie malowidła, ale wymagało długotrwałej, bardzo ostrożnej pracy i sporego doświadczenia konserwatora. Polichromowane tynki w mastabie Idut zostały naniesione na podłoże skalne o wielu nierównościach, w których zaprawa była mocno zakotwiona i jej oddzielenie wymagało odchylania płata, co groziło odklejeniem się licowania. Egipskie malowidła były zespolone z podłożem skalnym w nielicznych miejscach, ale oba elementy bardzo mocno łączyły się ze sobą.

62 Siła powodująca rozerwanie papieru wyprodukowanego maszynowo o gramaturze 12,5 g/m² i grubości 0,067 mm wynosi ok. $7 \mathrm{~N}$.

63 Siła powodująca rozerwanie papieru wyprodukowanego ręcznie o gramaturze $12,0 \mathrm{~g} / \mathrm{m}^{2}$ i grubości $0,048 \mathrm{~mm}$ wynosi ok. $14 \mathrm{~N}$.

64 Siła powodująca rozerwanie dwóch arkuszy papieru wyprodukowanego maszynowo o gramaturze $12,5 \mathrm{~g} / \mathrm{m}^{2}$ i grubości $0,067 \mathrm{~mm}$, sklejonych za pomoca funori, wynosi ok. 53 N. Siła powodująca rozerwanie papieru wyprodukowanego ręcznie o gramaturze $12,0 \mathrm{~g} / \mathrm{m}^{2}$ i grubości $0,048 \mathrm{~mm}$, sklejonych za pomoca funori, wynosi ok. 38 N. Badania wytrzymałości mechanicznej papierów i licowań na maszynie TIRAtest 27025 wykonał mgr J. Dzwonkowski w Laboratorium Technologicznym Instytutu Inżynierii Materiałów Polimerowych i Barwników w Toruniu. 
Wynikało to z klejących właściwości wilgotnego podłoża skalnego i inkrustacji solnych na granicy skała-tynk. Oddzielenie tynku w takich miejscach czasami wymaga postępowania bliższego metodzie stacco a masello niż distacco. W miejscach, gdzie tynk łączył się ze skała, przyczepność licowania była osłabiona z powodu podwyższonej wilgotności podłoża. Pomimo impregnacji zabezpieczającej, wprowadzenie wody (jako rozpuszczalnika licowania) stanowiło niebezpieczeństwo dla warstwy malarskiej i tynku, zbudowanych z materiałów rozpuszczalnych lub pęczniejących w wodzie. W trakcie przenoszenia malowidła nie stwierdzono zagrożenia mikrobiologicznego. Wilgotność względna w komorze grobowej Idut nie jest skrajnie wysoka, w okresie letnim dochodzi do 60\%. Większym zagrożeniem biologicznym dla malowideł może być naniesienie licowań z funori i długotrwałe pozostawienie ich na ścianie, przez co w miejscach połączeń tynku ze skałą zostaną narażone na lokalne oddziaływanie wilgoci z podłoża skalnego.

Eksperyment wykazał, że materiały zaproponowane przez stronę japońską Egyptian-Japanese Mission for Mastaba Idout raczej nie znajdą szerokiego zastosowania w Egipcie, gdzie warunki zabiegu, właściwości malowideł i ich podłoży zdecydowanie różnią się od występujących w Japonii. Zaproponowane przez Japończyków materiały, wywodzące się z ich bogatej kultury, mające szereg unikatowych cech, uzupełniają i wzbogacają asortyment środków konserwatorskich do przenoszenia malowideł. Wbrew oczekiwaniom pomysłodawców licowanie wykonane $\mathrm{z}$ tych materiałów nie okazało się uniwersalnym rozwiązaniem, za pomocą którego można łatwo i bezpiecznie przenosić wszelkie malowidła, niezależnie od technologii, techniki wykonania, stanu zachowania i lokalizacji. Licowania z funori i washi kozo moga być wykorzystywane do przenoszenia malowideł słabo połączonych z podłożem, łatwych do oddzielenia i całkowicie suchych. Doceniając intencję japońskich konserwatorów, którzy do ratowania skarbów kultury proponuja zastosowanie najcenniejszych materiałów, nie sposób nie zauważyć ich ograniczonych zdolności aplikacyjnych. W obliczu możliwości użycia tańszych i powszechnie dostępnych środków należy sądzić, że alternatywne wykorzystywanie washi kozo i funori nie będzie rozwiązaniem popularnym. 


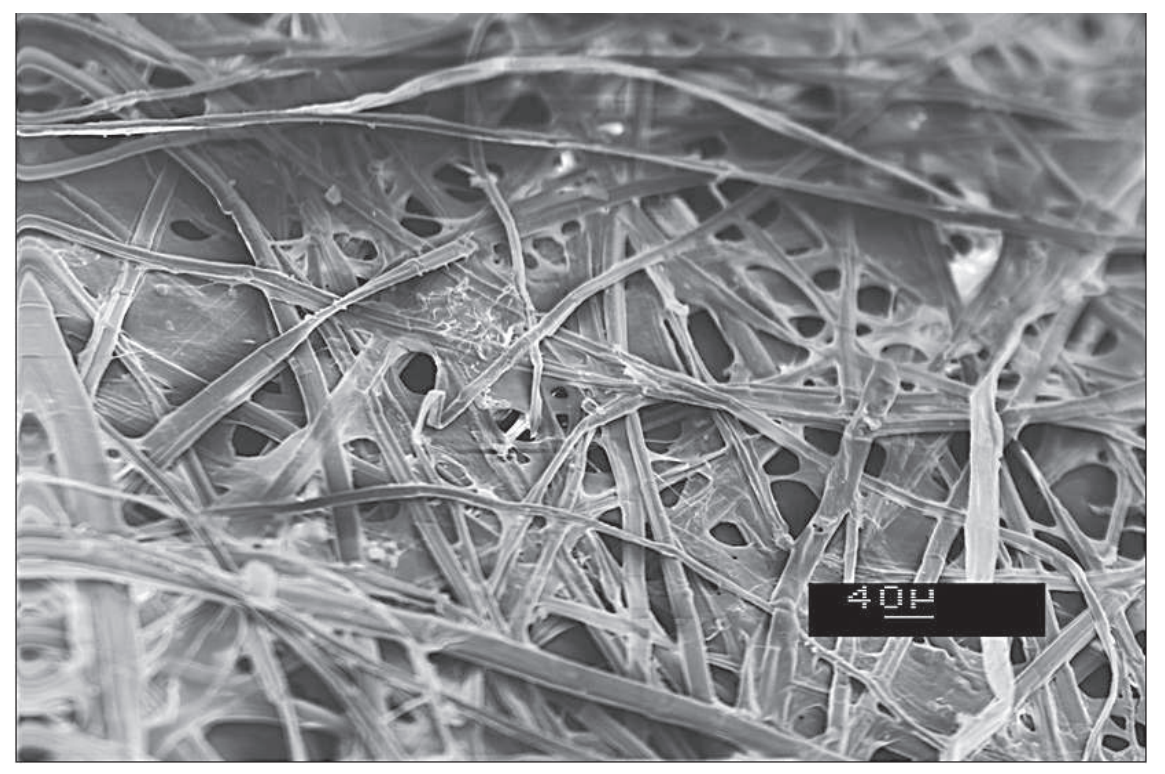

Il. 1. Obraz SEM washi kozo o gramaturze $12,0 \mathrm{~g} / \mathrm{m}^{2}$ i grubości $0,048 \mathrm{~mm}$ (fot. J. Szatkowski)

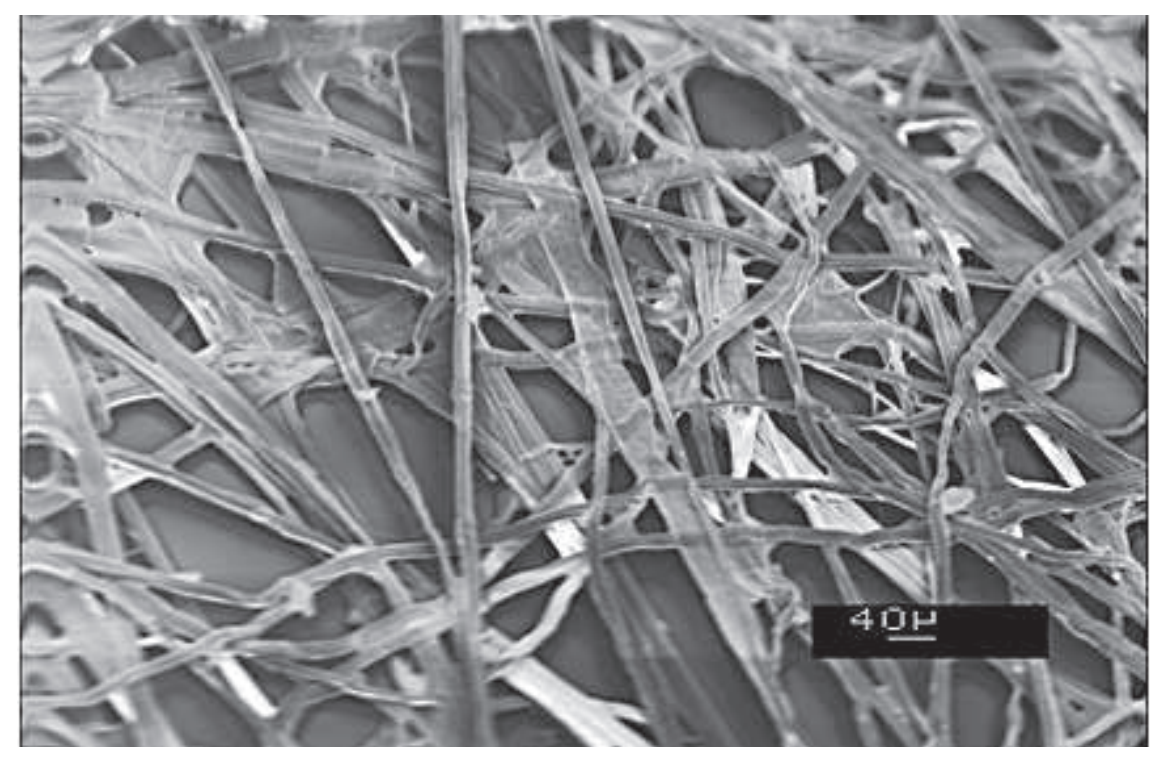

Il. 2. Obraz SEM kikaizuki washi kozo o gramaturze 12,5 g/m² i grubości 0,067 mm (fot. J. Szatkowski) 


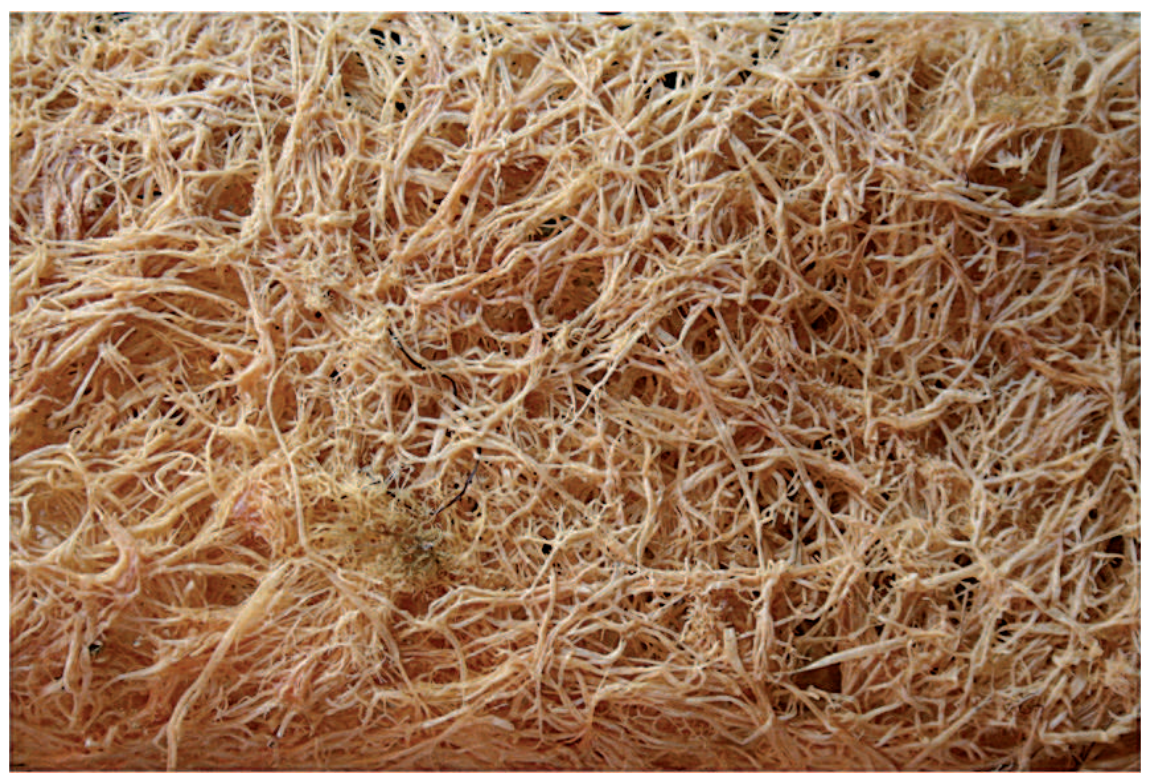

Il. 3. Wysuszone wodorosty Gloiopeltis furcata (fot. R. Rogal)

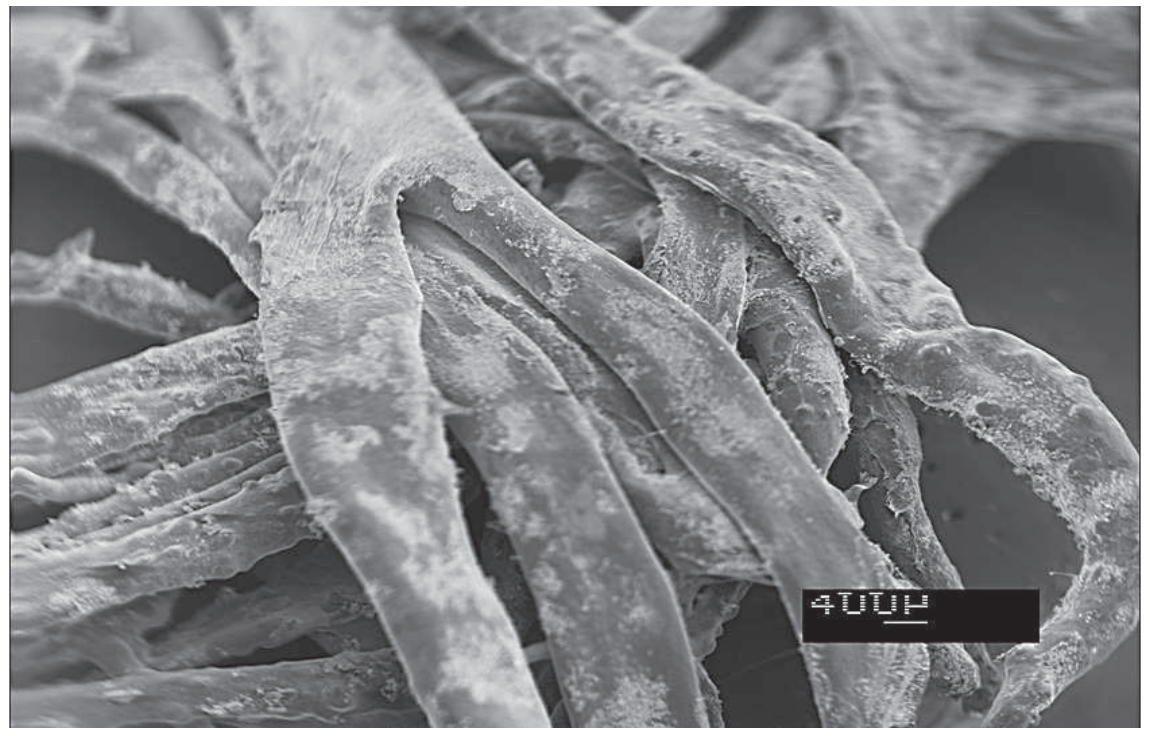

Il. 4. Obraz SEM Gloiopeltis furcata. Na powierzchni wodorostów widoczna sól wypłukiwana w czasie przygotowania funori (fot. J. Szatkowski) 


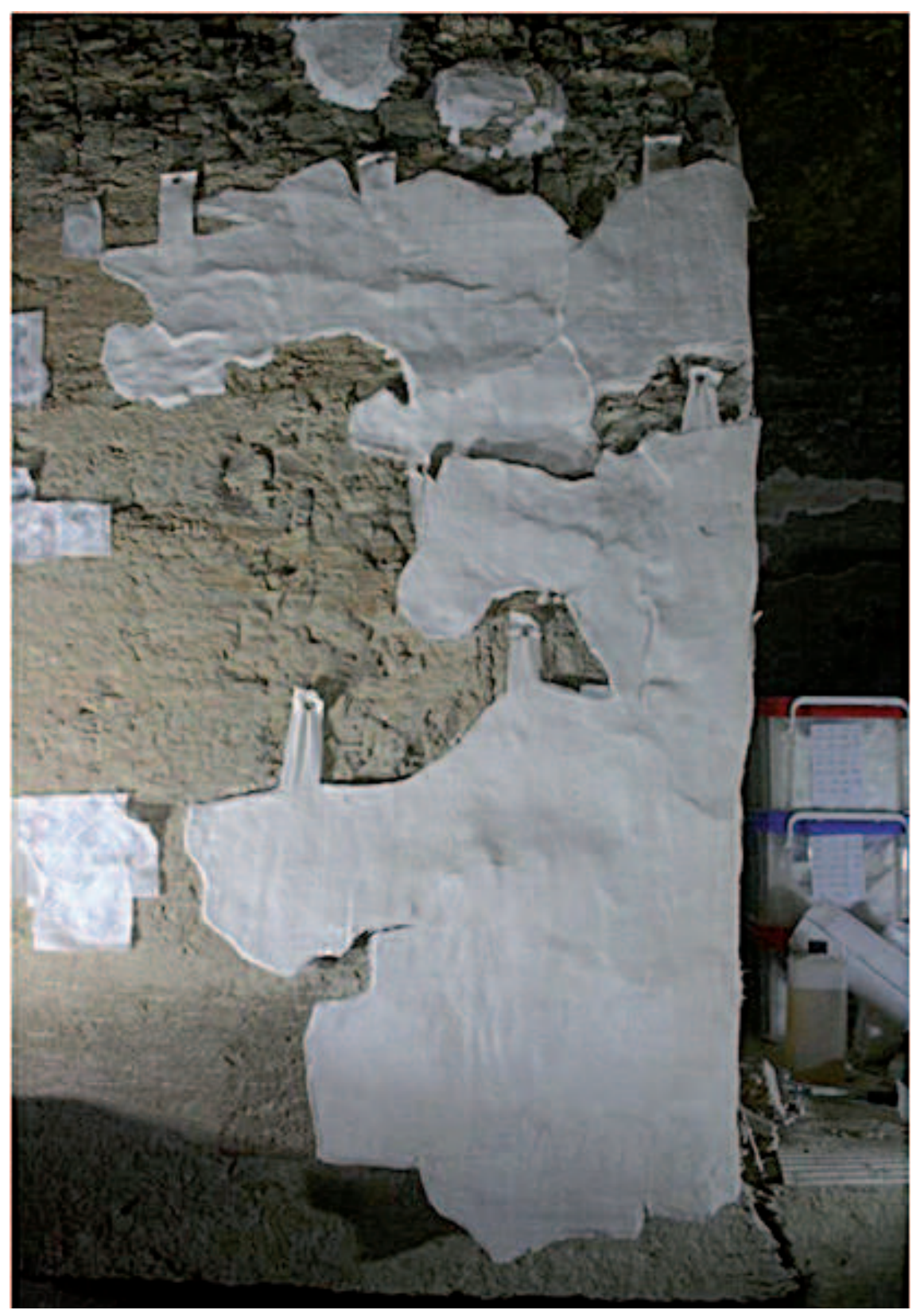

Il. 5. Warstwa licowania z washi kozo i funori naniesiona w 2005 r. na fragment malowidła w komorze grobowej mastaby Idut w Sakkarze (fot. R. Rogal) 


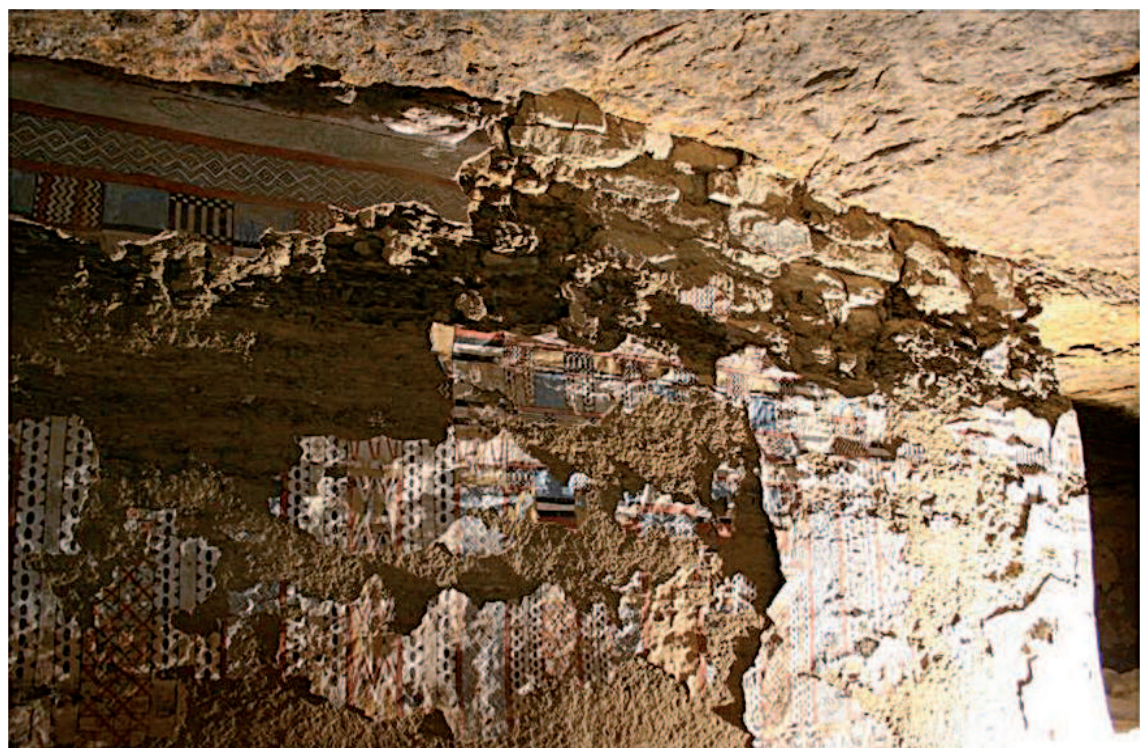

Il. 6. Fragment ściany zachodniej komory grobowej mastaby Idut w Sakkarze. Stan z 2005 r. przed rozpoczęciem prac konserwatorskich (fot. R. Rogal)

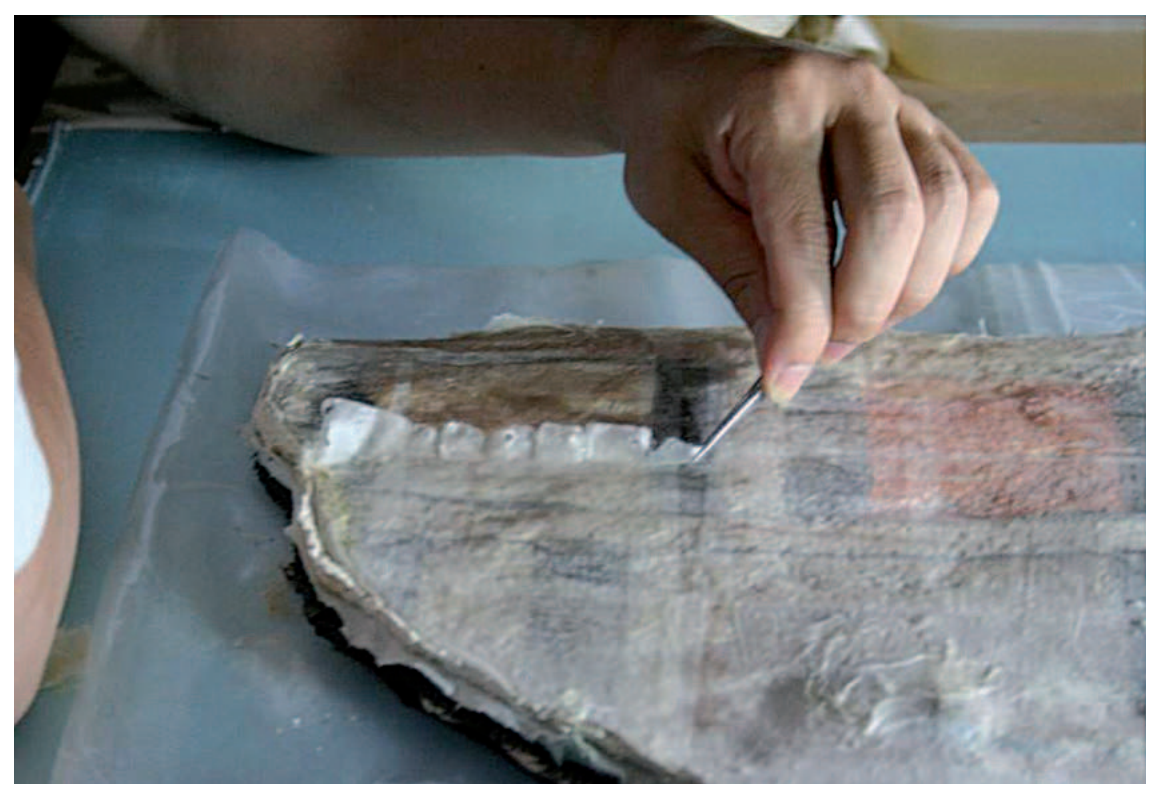

Il. 7. Usuwanie washi kozo i funori z powierzchni przeniesionego malowidła (fot. R. Rogal) 


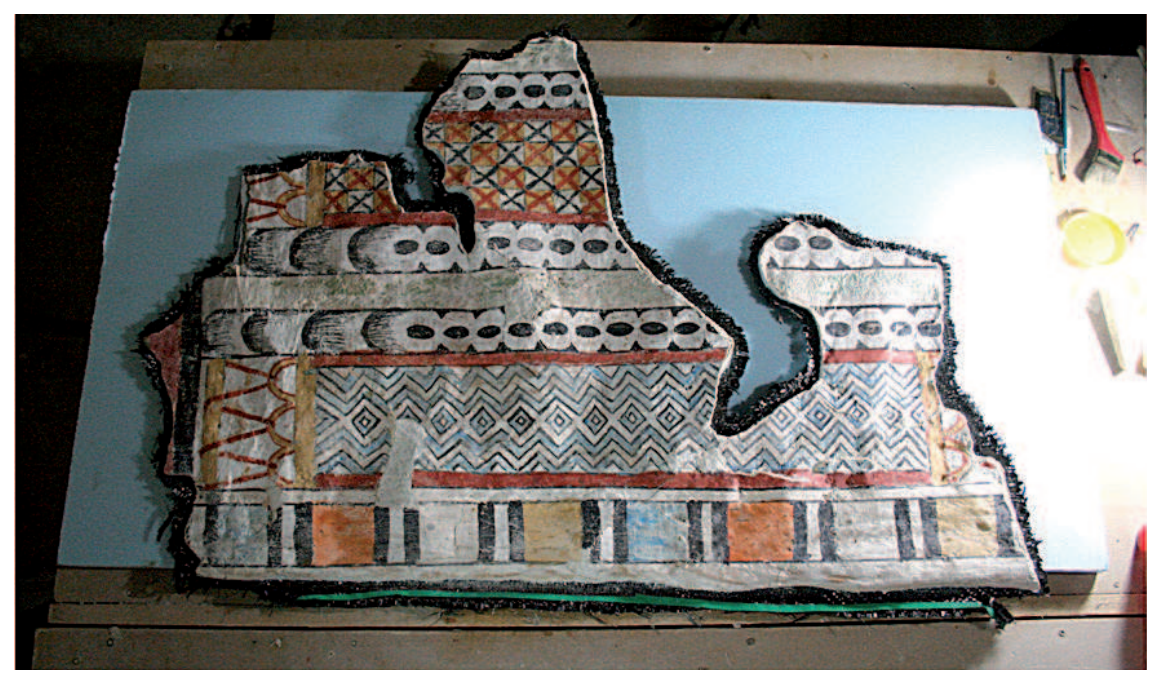

Il. 8. Fragment malowidła z komory grobowej mastaby Idut po usunięciu licowania (fot. R. Rogal)

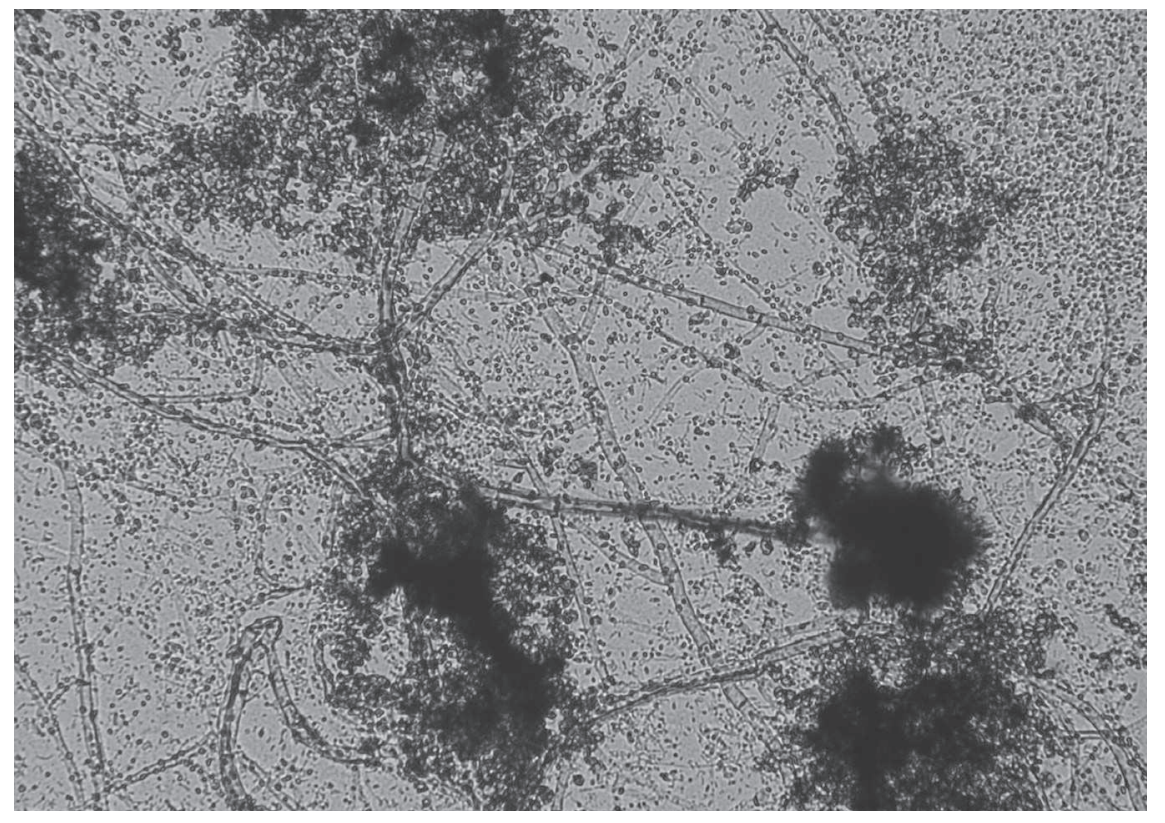

Il. 9. Kolonie bakterii oraz strzępki grzybni i aparaty konidialne grzyba pleśniowego (fot. J. Karbowska-Berent) 


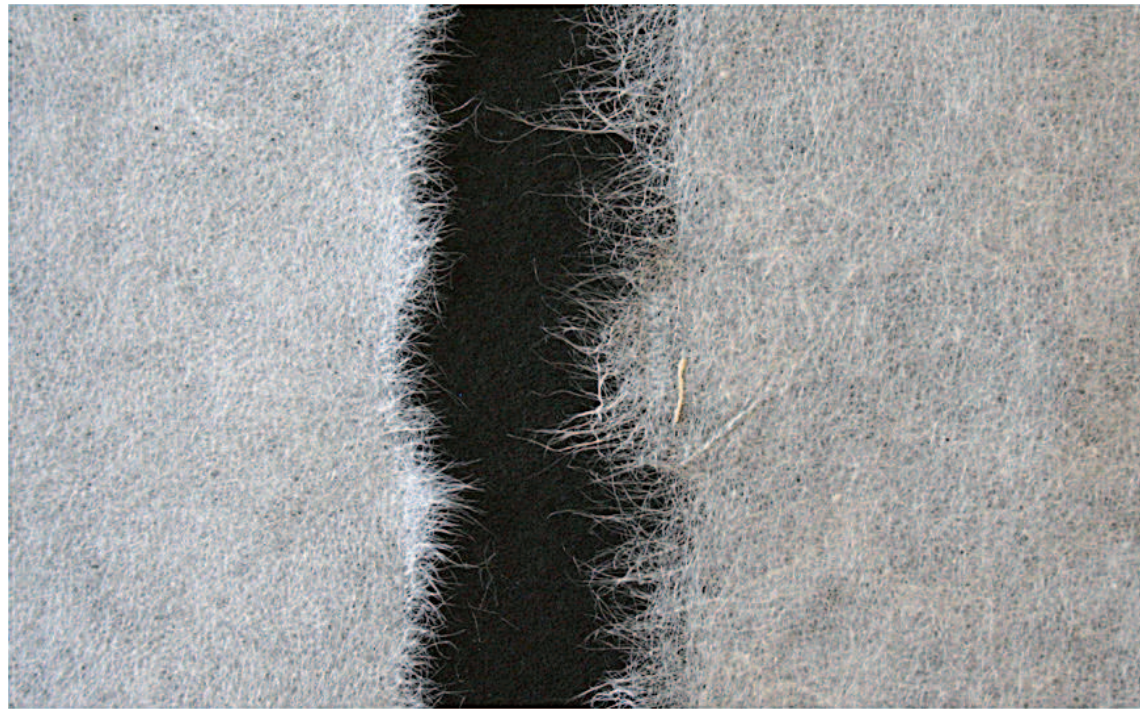

Il. 10. Porównanie długości włókien kozo w papierze otrzymywanym ręcznie i maszynowo (fot. R. Rogal)

\section{Summary}

\section{Washi kozo and funori as materials for facing mural paintings during transferring}

This paper aims for answering the question whether the hand-made kozo paper and a consolidating adhesive funori can be applied as elements of facing for transferring mural paintings. The history, technique of the making, properties and original use of those products are described, as well as their first application for transferring mural paintings in Japan. Facing made of traditional Japanese materials has been subject to durability tests and its biological resistance has been checked. It has also been compared with facing made of machine-made kozo paper and methyl-cellulose. The source of author's practical experience was transferring a fragment of mural painting in an ancient Egyptian tomb. Laboratory tests and practical conservation experience have demonstrated limited possibilities of the use of facing made of traditional Japanese materials. 